
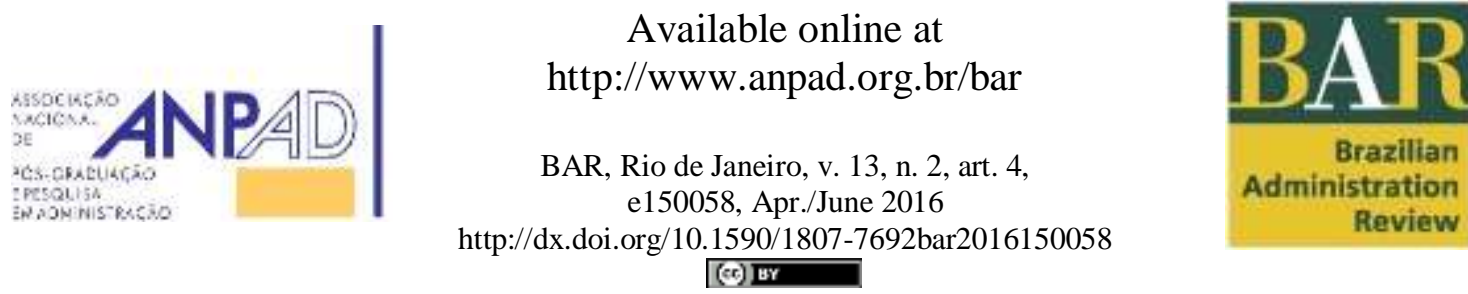

Administration

Review

\title{
Private Equity and Venture Capital Funds: What Drives the Demand and Supply?
}

\author{
Ricardo dos Santos Dias ${ }^{1}$ \\ Marcelo Alvaro da Silva Macedo ${ }^{2}$ \\ Universidade Federal do Espírito Santo ${ }^{1}$ \\ Universidade Federal do Rio de Janeiro ${ }^{2}$
}

Received 29 September 2015; received in revised form in 27 April 2016 (this paper has been with the authors for three revisions); accepted in 1 May 2016; published online 13 June 2016. 


\begin{abstract}
This study investigates determinants for the demand and supply for PE/VC funds. Six factors were identified through Factor Analysis: Economic Activity, Development of Stock Markets, Corporate Governance, Social and Environmental Development, Entrepreneurship and Taxation. These factors were defined through 25 variables and transformed into five factors by factor analysis. The resulting factors were used in econometric models for investigating relationships among said factors and the fundraising of PE/VC funds first, and then with the amount invested by PE/VC funds. The results indicate that investments are adversely affected by the depth of the capital market: the PE/VC funds seek an exit strategy which the stock market offers through IPOs (Initial Public Offering). Other significant factors were protection of investors, social and environmental development and level of entrepreneurship. Different from expected, the economic activity was of low impact on demand. The result seems controversial but its lack of significance highlights the importance of the capital market (through IPOs as a way of disinvestment) as a key driver of the PE/VC market. Taxation was also not significant to the demand side, a fact which denotes that the government can influence the local PE/VC market, and that it should offer high enough discount rates or tax incentives to mitigate the effect of other barriers faced by the PE/VC market.
\end{abstract}

Key words: private equity; venture capital; factor analysis. 


\section{Introduction}

The Private Equity/Venture Capital (PE/VC) industry has grown in recent years especially in developing economies, where a considerable increase in financing activities has been observed. One possible reason could be the search for different paybacks in economies that go through an economic and institutional maturity, given that developed markets have been evidencing a decrease in profitability levels, since the 1990s (Comodo, 2009).

Despite it being widely disseminated around the world, the PE/VC activity is mostly concentrated in the United States of America and the United Kingdom, which together account for approximately $60 \%$ of the raised capital, although there has been a continuous reduction in the difference, compared to other countries. Brazil, China and India, for example, have created conditions for the development of the PE/VC activity, hence, they are the ones that have been successful in fundraising (Bain \& Company Inc., 2013).

The fundraising and resource allocation process by $\mathrm{PE} / \mathrm{VC}$ funds can boost the internal market of a country. So, it is intuitively possible to assert that countries will battle for international investments of $\mathrm{PE} / \mathrm{VC}$ in an attempt to bring these resources to their market by creating attractive conditions for PE/VC managers. Therefore, it is the theoretical gap that this study seeks to fill: through the investigation of the factors influencing supply and demand PE/VC, it is possible to understand what makes a country more interesting for the attraction of international capital.

The main goal of this paper is to understand which factors influence the PE/VC market. To achieve it, we separately analyzed the supply and demand sides of transactions. Twenty-five variables were chosen consistent with the existing literature. Using Factor Analysis, we modeled variables that possibly affect the demand of the PE/VC. These factors include macroeconomic, financial, corporate governance, entrepreneurship, social and environmental development variables. We then exploited regressions made up of 25 countries over a six-year period (2006-2011).

The results indicate that investments are adversely affected by the depth of the capital market: PE/VC funds search for an exit strategy that the stock market can offer by means of IPOs (Initial Public Offering). Other significant factors were the protection of investors, environmental development and the level of entrepreneurship. Different from expected, the economic activity was negative significant to demand side.

The paper is structured as follows: The next section explains the market functioning and summarizes the findings of the existing evaluation of key drivers of the PE/VC. Third section shows the methodology aspects concerning dataset, multivariate data analysis and the models. The empirical results are interpreted in fourth section. And final section presents the conclusions.

\section{Market functioning and literature review}

Private Equity (PE) can be defined as business investments in companies that are not listed in the stock market. This type of acquisition has natural characteristics such as low liquidity, expectation of higher returns in the long-term and higher risk. Investments like this have also invariably been characterized by the informational asymmetry, since managers of PEs are seeking business opportunities that have not been priced by the market, which can be acquired at an attractive discount for a fair price and that have a valuation perspective (Agência Brasileira de Desenvolvimento Industrial [ABDI], 2011; Almeida, 2013; Gionelli, 2008; Lopes \& Furtado, 2006).

Investments in $\mathrm{PE} / \mathrm{VC}$ are temporary and they usually take more than five years, thus being considered long-term investments. Such opportunities are identified by the company's stage of development. Despite it has been separately specified, it is possible to infer that Venture Capital is a type of Private Equity, so that companies receiving investments in their early stage of development (such 
as startups), and the term Private Equity are used to designate companies already established in the market.

The PE/VC market has three agents: management organizations, investors, and invested companies. Simplifying the dynamic market, investors apply their capital in investment vehicles that are driven by management organizations, which in turn, buy participation in portfolio companies for a specified period of time. At the end of this period, managers undo the long positions and assign the appropriate parties to investors, leaving a residual portion of that amount to pay for the service provided. Figure 1 illustrates the agents and their interactions below:

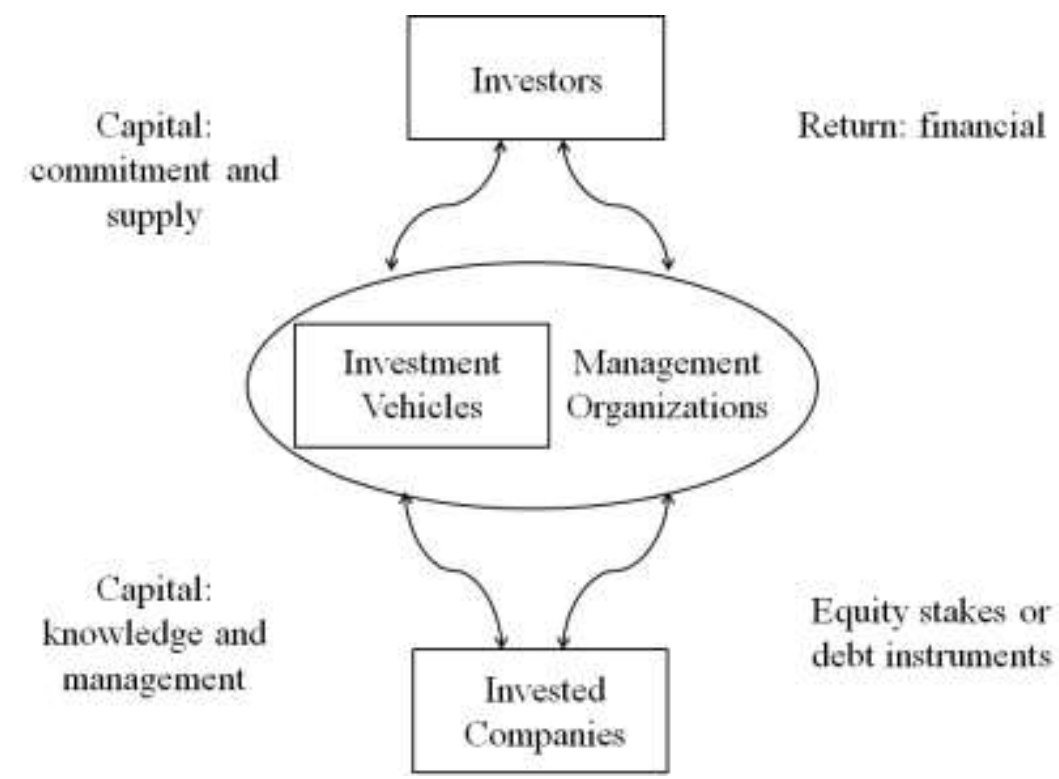

Figure 1. Agents of PE/VC Market

Source: Almeida, A. A. (2013). A influência do private equity e venture capital sobre a informatividade dos lucros no mercado brasileiro (p. 14) (Dissertação de Mestrado). Programa de Pós-Graduação em Ciências Contábeis, Universidade Federal do Espírito Santo, ES, Brasil. Retrieved from http://portais4.ufes.br/posgrad/teses/tese_5939_ DISSERTA\%C7\%C3O\%20ANDR\%C9\%20PDF.pdf

Some studies discuss the determinant attributes to the activity of the PE/VC market, but most of them deal with Private Equity markets and Venture Capital markets separately. The reasons for this are obvious: while some attributes have the greatest impact on early-stage companies, there are other attributes that directly affect mature companies already established in the market (Jeng \& Wells, 2000). However, the intention is not to discuss these differences, and as consequence, both segments will be treated as a single element.

The Private Equity and Venture Capital market is an important object of study in academic research. Some authors have focused on the economic impact of PE/VC funds (Engel, 2002; Hellmann \& Puri, 2002; Kortum \& Lerner, 2000), while other studies have focused on fund performance and management skills (Kaplan \& Schoar, 2005).

Considering performance and value creation, Jensen (1989) argues that public companies suffer the entrenchment of management, allowing possible cash flow deviations, thus decreasing efficiency. Therefore, Leveraged Buyouts generate value through significant improvement of operational processes.

In their research, Muscarella and Vetsuypens (1990) analyzed 72 companies that have undergone Reverse Leveraged Buyout (RLBO) and shown an improvement in profitability, while as a private company, the sample achieved $34 \%$ increase in its value. This result is due to organizational restructuring, forced by the entry of a $\mathrm{PE} / \mathrm{VC}$ fund in a management that enabled the reduction of costs 
resulting in greater operational efficiency. Similar results can be found in Kaplan (1989), Kaplan and Schoar (2005) and Phalippou and Gottschalg (2007).

Contrary to expectations, only few of those papers attempted to understand the determinants of PE/VC. Studying the US market, Gompers and Lerner (1998) found out that performance, size and the fund age are important factors to raise more capital, additionally that PE/VC fundraising reacts positively to GDP growth and increases R\&D expenditure. Lee and Peterson (2000) and Baughn and Neupert (2003) explored similar results and also argued that the national culture shapes individual orientation and consequently the environmental condition that ultimately leads to different entrepreneurship levels.

Romain and Pottelsberghe de la Potterie (2004) investigated the intensity determinants of the VC market in sixteen countries using panel regressions and found evidence that the market reacts positively and significantly to GDP growth. They also concluded that technological opportunity indicators (such as increased investment in research and development and number of patents) significantly influence the VC market.

Jeng and Wells (2000) argue that the PE/VC market evidences strong fluctuations over time and that the driving force of these fluctuations is the IPOs, making the development of the capital market one of the determining factors. Despite this result, fund managers tend not to take the companies they invest in, in countries where the most developed capital markets seek more IPO opportunities, as Israeli technology companies have done in NASDAQ. The increased costs and monitoring efforts of geographically distant companies partially explain this phenomenon.

Black and Gilson (1998) found similar results; however, they divided countries into two types: countries with centralization in the capital markets and countries with centralization in the banking system. This division will be the core of the development of the PE/VC market, since the centralization in the capital market is a precondition for the existence of a PE/VC vibrant market, given that a welldeveloped capital market makes an exit strategy possible through a public offer. In the same way, Balboa and Martí (2004) showed dependence between the growth of fundraising volume by PE/VC funds and the market liquidity in the previous year.

The legal environment also affects significantly as demonstrated by La Porta, Lopez-de-Silanes, Shleifer and Vishny (1997): a good legal environment protects potential financiers against expropriation by entrepreneurs increasing their willingness to supply resources to the funds in exchange for securities. Therefore, it extends the market range. The study evaluated laws protecting investors in 49 countries and showed that Common Law countries provide greater protection to investors than Civil Law countries. Some other evidences were gathered in the table below:

Table 1

\section{Previous Evidence}

\begin{tabular}{lr}
\hline \multicolumn{1}{c}{ Authors } & \multicolumn{1}{c}{ Results } \\
\hline $\begin{array}{l}\text { Black and Gilson (1998) } \\
\text { Jeng and Wells (2000) }\end{array}$ & $\begin{array}{r}\text { Economies with more developed capital market are more active in private } \\
\text { equity than economy centered on banks. }\end{array}$ \\
\cline { 2 - 2 } & 1) IPO as driving force for Private Equity investments; \\
\hline Balboa and Martín (2004) & The volume growth in t of investments in Private Equity is partially explained \\
& \\
&
\end{tabular}

Continues 
Table 1 (continued)

\begin{tabular}{|c|c|}
\hline Authors & Results \\
\hline Gompers and Lerner (2001) & $\begin{array}{c}\text { The level of the market liquidity influences the level of investments in Private } \\
\text { Equity }\end{array}$ \\
\hline \multirow[t]{2}{*}{ Gompers and Lerner (1998) } & $\begin{array}{l}\text { 1) The annual growth in Private Equity is affected by regulatory changes } \\
\text { relating to pension funds, the growth of the economy as a whole, the fund's } \\
\text { performance in question and its reputation; }\end{array}$ \\
\hline & 2) The tax on capital gains also influence the Private Equity activity \\
\hline $\begin{array}{l}\text { Cumming, Fleming and } \\
\text { Schwienbacher }(2006)\end{array}$ & $\begin{array}{l}\text { The quality of the legal system is more likely to facilitate the activities of } \\
\text { private equity than the size of the stock market. The legal origin and } \\
\text { accounting standards have significant impact on the governance of private } \\
\text { equity investments. }\end{array}$ \\
\hline Armour and Cumming (2008) & $\begin{array}{c}\text { Government programs hinder more, rather than help the development of } \\
\text { private equity markets. }\end{array}$ \\
\hline Cullen and Gordon (2002) & Taxes affect the entry and exit of business. \\
\hline Megginsson (2002) & $\begin{array}{l}\text { Countries with growing } \mathrm{R} \& \mathrm{D} \text {, especially in the national universities and } \\
\text { laboratories, are important for the capital industry risk. }\end{array}$ \\
\hline Schertler (2003) & $\begin{array}{l}\text { The number of employees in } R \& D \text { and the number of patents as a proxy of } \\
\text { human capital has strong significance in PE. }\end{array}$ \\
\hline $\begin{array}{l}\text { Groh, Liechtenstein and Lieser } \\
(2010)\end{array}$ & $\begin{array}{l}\text { Investor protection and capital market are very important determinants for } \\
\text { attractiveness of PE/VC market. }\end{array}$ \\
\hline
\end{tabular}

As described, there are several determinants for PE/VC. Some of them can be observed at the macroeconomic level while others are microeconomic factors. Groh et al. (2010) identified what was most attractive for financiers, for it used 42 parameters that made up six factors: economic activity, taxes, investor protection, entrepreneurial culture, social and environmental development, depth of capital market.

The following section presents these variables, how they were measured and grouped by factor analysis. We then developed a theoretical model that aimed at understanding the impact of these factors in the PE/VC market, especially on the demand side.

\section{Methodology Aspects}

Table 2 summarizes the variables that will be examined for construction of factors to best represent the constructs mentioned. It also shows the source of each variable, as follows: 
Table 2

Constructs and Variables Used

\begin{tabular}{|c|c|c|c|c|}
\hline \multicolumn{3}{|c|}{ Construct } & Variable & Source \\
\hline \multirow{7}{*}{\multicolumn{3}{|c|}{ Intensity of Capital Market activity }} & IPO volume (\% of GDP) & \multirow{5}{*}{ World Bank } \\
\hline & & & IPO numbers & \\
\hline & & & $\begin{array}{l}\text { Private credit available for banks and financial } \\
\text { institutions ( } \% \text { of GDP) }\end{array}$ & \\
\hline & & & $\begin{array}{l}\text { Number of banks (total of agencies per 100,000 } \\
\text { habitants) }\end{array}$ & \\
\hline & & & Numbers of listed companies & \\
\hline & & & Merge and Acquisition (\% of GDP) & \multirow{2}{*}{ Thomson One } \\
\hline & & & Merge and Acquisition (numbers of negotiation) & \\
\hline \multirow{3}{*}{\multicolumn{3}{|c|}{$\begin{array}{l}\text { Friendly environment for } \\
\text { entrepreneurship }\end{array}$}} & Number of procedures to open a new business & \multirow{3}{*}{ World Bank } \\
\hline & & & Number of trademarks and patents & \\
\hline & & & $\begin{array}{l}\text { Percentage of per capita income for the payment } \\
\text { of fees and other expenses for compliance with } \\
\text { legal records }\end{array}$ & \\
\hline \multirow{3}{*}{\multicolumn{3}{|c|}{ Economic Activity }} & GDP per capita & \multirow{3}{*}{ World Bank } \\
\hline & & & GDP grow $(\%)$ & \\
\hline & & & Price Level $(2005$ = 100) & \\
\hline \multirow{8}{*}{\multicolumn{2}{|c|}{$\begin{array}{c}\text { Social } \\
\text { Development }\end{array}$}} & \multirow{3}{*}{ Education } & Number of researchers per million inhabitants & \multirow{3}{*}{ World Bank } \\
\hline & & & $\begin{array}{l}\text { Expenditure per student, primary (\% of GDP per } \\
\text { capita) }\end{array}$ & \\
\hline & & & $\begin{array}{l}\text { Expenditure per student, secondary (\% of GDP } \\
\text { per capita) }\end{array}$ & \\
\hline & & \multirow{3}{*}{ Communication } & Internet users (per 100 people) & \multirow{3}{*}{ World Bank } \\
\hline & & & $\begin{array}{l}\text { Fixed broadband Internet subscribers (per } 100 \\
\text { people) }\end{array}$ & \\
\hline & & & Telephone lines (per 100 people) & \\
\hline & & \multirow{2}{*}{ Crime } & Intentional homicides (per 100,000 people) & World Bank \\
\hline & & & Corruption Perception Index & Transparency.org \\
\hline \multirow{3}{*}{\multicolumn{3}{|c|}{ Investor Protection }} & Business extent of disclosure index ${ }^{a}$ & \multirow{3}{*}{ World Bank } \\
\hline & & & Ease of Shareholder Suits index ${ }^{b}$ & \\
\hline & & & Strength of legal rights index ${ }^{c}$ & \\
\hline \multicolumn{3}{|c|}{ Taxes } & Corporate Tax & Thomson One \\
\hline
\end{tabular}

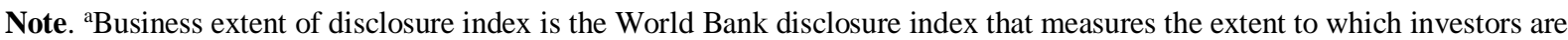
protected through disclosure of ownership and financial information. Ranges from 0 (less disclosure) to 10 (more disclosure); ${ }^{b}$ Ease of Shareholder Suits index is the World Bank index that measures the shareholders' ability to sue officers and directors for misconduct. The index ranges from 0 (little to no ability to file suit) to 10 (greater ability to file suit); ${ }^{c}$ Strength of legal rights index is the strength of legal rights index that measures the level to which collateral and bankruptcy laws protect the rights of borrowers and lenders and thus facilitate lending. Ranges from 0 (weak) to 12 (strong). 
First, it is important to state that our data series is driven by previous literature findings. Our data covers the 2006 to 2011 period, and was composed of 25 countries: Argentina, South Africa, Australia, Brazil, Canada, Chile, Colombia, South Korea, Spain, USA, Finland, France, Holland, India, Israel, Italy, Japan, Malaysia, Mexico, Norway, UK, Russia, Germany, Sweden and Switzerland.

The selection of countries was also imposed by data availability. The major task at that point was to find appropriate variables that reveal the characteristics of the constructs. Table 2 shows the constructs, correlate variables and their sources.

Table 2 shows the constructs and variables we used to describe them; a total of 25 selected variables divided in 6 constructs. The construct Social Development was divided into 3 sub-constructs: education, crime and communication. The crime and education variables were used in previous research to describe the construct under discussion. Communication variables were added since weak telecommunication structures disturb the development of the economy and market competitiveness (Frieden, 2005) can have a strong impact on businesses related to technology: a common characteristic of startups financed by venture capital.

The study aims to understand the forces that influence the fundraising (supply side) and resource allocation process (demand side). Thus, the formed factors were used in econometric models taking the sum of the resources raised to measure its impact on the supply side, as dependent variables. Next, we tested a regression model using the same factors against the sum of the resources invested by PE/VC funds in companies as the dependent variable. A restrictive factor in obtaining this kind of data was the fact that those negotiations between PE/VC funds and firms are private, making its disclosure optional.

For this reason, the study was limited, in investigation, to the use of existing public information, which in this case was obtained from the Thomson Reuters database. The next dependent variables were formally defined as follow:

Fundraising (FUNDR): Total funds raised by PE/VC funds coming from investors. Gompers and Lerner (1998) define these resources as the desire of investors to deposit their capital excess in PE /

VC funds. Quantitatively, it is measured by the sum of the resources of all resident funds in each country.

Invested Resources (INVM): the amount of resources invested on the demand side of the PE/VC market. The demand comes from entrepreneurs interested in obtaining resources from PE/VC funds. Numerically, it is the amount of resources invested by the PE/VC funds of each country in the sample.

\section{Factor Analysis}

Factor analysis is a technique that aims to synthesize a set of interrelated variables in order to find common factors. It allows the reduction of data into a smaller set of hypothetical variables that can compress what is common among the initial variables (Fávero, Belfiore, Silva, \& Chan, 2009; Kim \& Mueller, 1978).

Fávero, Belfiore, Silva and Chan (2009) divides the factor analysis into confirmatory and exploratory, the first being performed when there is solid prior knowledge of how the variables are related and, therefore, it is assumed that the factor structure is known. In the exploratory factor analysis there is little or no prior knowledge about the behavior of variables.

Due to the characteristics of the study, we used exploratory factor analysis since there are previous studies that report the use of these attributes (Groh, Liechtenstein, \& Lieser, 2010). Nonetheless, there is disagreement in the literature about the variables used for the formation of factors. Since the purpose is to summarize variables, we used the Principal Component Analysis (PCA) and R-Type that, according 
to Hair, Black, Babin, Anderson and Tatham (2005), applies to a correlation matrix of variables to identify the latent dimensions.

Factor analysis becomes crucial due to the number of variables used (25), which would cause an impact on the parsimony of the econometric model since the aim is to evaluate a model that best describes the relationship among the variables and, at the same time, to be as simple as possible. Thus, for each construct, a Factor analysis was used in order to extract a smaller data set, where the priority was the generation of a single factor for each construct.

Figure 2 demonstrates the use of this method in the study, where the ellipses represent the constructs, the rectangles represent the variables used to describe the overlying construct and the triangles represent the factors resulting from the use of the technique:
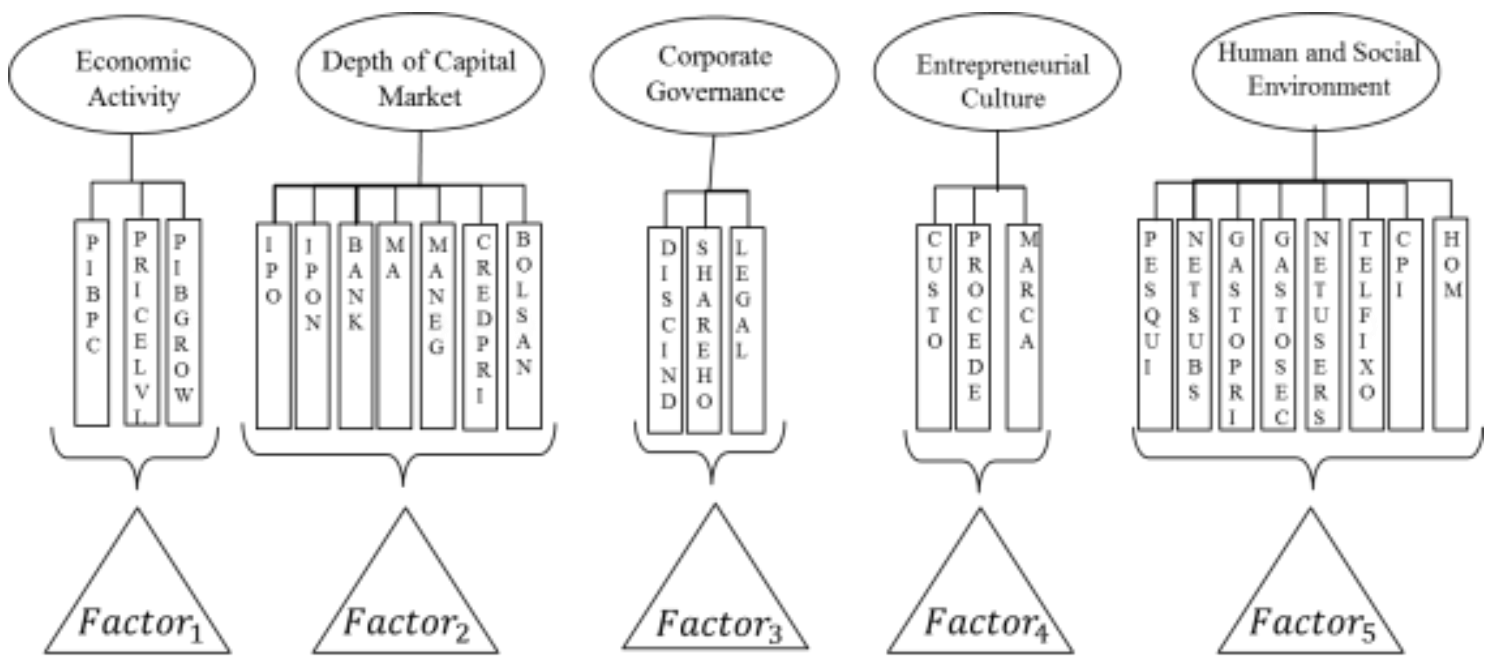

Figure 2. Factor Analysis Scheme

\section{Econometric Models}

Considering the previous studies and our proposal, we modeled a regression using the resulting factors to examine their impact on the dependent variable, as explanatory variables, Pooled regressions were used to describe the following linear relationship model between the variables:

$$
\begin{aligned}
& F U N D R_{i}=\beta_{0}+\beta_{1} E_{C O}+\beta_{2} M_{C A P}+\beta_{3} I N V P R O T_{i}+\beta_{4} D S O_{i}+ \\
& \beta_{5} E M P_{i}+\beta_{6} \operatorname{CORPTX}_{i}+\varepsilon_{i} \\
& I N V M_{i}=\beta_{0}+\beta_{1} E C O_{i}+\beta_{2} M C A P_{i}+\beta_{3} I N V P R O T_{i}+\beta_{4} D_{S O}+\beta_{5} E M P_{i}+ \\
& \beta_{6} \operatorname{CORPTX}_{i}+\varepsilon_{i}
\end{aligned}
$$

In both cases, we reported fixed effects as robustness check (Hausman's test showed fixed effects instead of random effects). In the E1 model, FUNDR is the number of resources raised by PE/VC funds. In the E2 model, INVM is the amount invested by PE/VC funds in firms. The independent variables are the same for both regressions, where: ECO is Economic Activity factor, MCAP is factor of capital market, INVPROT is factor of investor protection, DSO is social development factor, EMP is entrepreneurial culture factor, and CORPTX is a variable for taxes, measuring the Corporate Tax. The models were preliminarily tested using the natural logarithm of the dependent variables, but the results remained unchanged and therefore were not reported.

A positive and significant relationship with the economic activity is expected $\left(\beta_{1}\right.$, since all the environmental performance also stems from the economic behavior of the country). Groh et al. (2010) 
argue that the size of the economy is an indicator of the number of organizations and general opportunities flow.

The previous literature reveals that the depth of capital market $\left(\beta_{2}\right.$ has a strong impact on the market $\mathrm{PE} / \mathrm{VC}$ and a positive and significant relationship is expected). Consequently, a positive and significant relationship with $\beta_{3}$, as described by La Porta et al. (1997), is expected. $\beta_{4}$ reflects the impact of environmental structure and a positive relationship is expected. $\beta_{5}$ reflects the influence of entrepreneurial culture and it is expected to have a positive relationship: more available projects allow managers to choose those with the highest potential growth. Corporate taxation $\left(\beta_{6}\right)$ has a negative impact on the volume of PE/VC as described by La Porta et al. (1997) and for this reason, a negative relationship is foreseen.

\section{Empirical Results}

Table 3 shows the descriptive statistics of the variables commented on the theoretical framework and methodology divided by construct. Looking at the table below, the mean and median have values similar to the GDPPC, GDPGROW, PRICELVL, BANK, CREDPRIV, DISCINDEX, SHAREHD, LEGAL, PROCEDE, GASTOPRIM GASTOSEC, CPI and CORPTX variables. This shows possible evidence of normal distribution, but this analysis is not conclusive and a formal test is required. For this purpose, the Shapiro-Wilk test was executed. Only six variables did not reject the null hypothesis of normality (SHAREHD, LEGAL, PROCEDE, GASTOPRI, GASTOSEC, and CORPTX):

Table 3

Descriptive Analysis

\begin{tabular}{|c|c|c|c|c|c|c|c|c|c|}
\hline Const. & Variables & Mean & Med & St. Dev. & Kurt & Asm & Min & Max & Num. \\
\hline \multirow[t]{3}{*}{ ECO } & GDPPC & 31199.16 & 34673.83 & 21811.06 & 0.02 & 0.56 & 830.16 & 99091.09 & 150 \\
\hline & GDPGROW & 2.47 & 2.71 & 3.45 & 0.79 & -0.54 & -8.54 & 10.26 & 150 \\
\hline & PRICELVL & 113.55 & 109.57 & 14.26 & 5.40 & 2.21 & 99.30 & 176.85 & 150 \\
\hline \multirow{7}{*}{$\begin{array}{l}\text { CAP. } \\
\text { MARK }\end{array}$} & IPO & 6129.77 & 2041.02 & 13376.55 & 23.07 & 4.48 & 0.00 & 96877.73 & 144 \\
\hline & IPON & 46.05 & 13.00 & 85.63 & 14.32 & 3.55 & 0.00 & 508.00 & 144 \\
\hline & BANK & 28.52 & 22.52 & 20.47 & 4.23 & 1.97 & 6.06 & 105.25 & 149 \\
\hline & MA & 99306.49 & 34766.21 & 228408.90 & 25.52 & 4.81 & 134.32 & 1675895.24 & 135 \\
\hline & MANEG & 1183.43 & 678.00 & 1771.96 & 13.39 & 3.49 & 51.00 & 10571.00 & 135 \\
\hline & BOLSAN & 1303.80 & 411.50 & 1551.28 & 0.22 & 1.26 & 79.00 & 5603.00 & 150 \\
\hline & CREDPRIV & 112.77 & 111.26 & 58.07 & -1.08 & 0.00 & 13.03 & 215.06 & 142 \\
\hline \multirow{6}{*}{$\begin{array}{l}\text { INVEST. } \\
\text { PROTEC }\end{array}$} & DISCINDEX & 6.74 & 7.00 & 2.13 & 2.49 & -1.16 & 0.00 & 10.00 & 150 \\
\hline & SHAREHD & 6.49 & 7.00 & 1.64 & -0.65 & -0.36 & 3.00 & 9.00 & 150 \\
\hline & LEGAL & 6.68 & 7.00 & 2.08 & -0.81 & -0.33 & 3.00 & 10.00 & 150 \\
\hline & PROCEDE & 7.37 & 7.50 & 3.29 & -0.19 & 0.38 & 1.00 & 16.00 & 150 \\
\hline & CUSTO & 10.00 & 5.90 & 13.82 & 11.30 & 3.13 & 0.40 & 78.40 & 150 \\
\hline & MARCA & 67331.83 & 47717.50 & 61666.71 & 4.94 & 2.07 & 5447.00 & 306049.00 & 144 \\
\hline
\end{tabular}


Table 3 (continued)

\begin{tabular}{lcrrrrrrrr}
\hline Const. & Variables & Mean & Med & St. Dev. & Kurt & Asm & Min & Max & Num. \\
\hline SDE & PESQUI & 2971.81 & 3185.78 & 2133.56 & -0.88 & 0.25 & 154.00 & 7717.48 & 122 \\
& GASTOPRIM & 18.64 & 18.43 & 4.20 & 0.08 & -0.30 & 7.07 & 28.35 & 125 \\
& GASTOSEC & 22.46 & 23.77 & 6.11 & -0.78 & 0.06 & 9.97 & 36.53 & 127 \\
& NETUSERS & 59.01 & 68.75 & 25.69 & -0.89 & -0.59 & 2.81 & 93.49 & 150 \\
& TELFIXO & 38.00 & 43.41 & 17.82 & -1.11 & -0.24 & 2.68 & 67.12 & 150 \\
& NETSUBS & 19.59 & 23.11 & 11.92 & -1.38 & -0.25 & 0.20 & 38.99 & 149 \\
& CPI & 6.32 & 6.90 & 2.27 & -1.36 & -0.28 & 2.10 & 9.60 & 150 \\
& HOM & 6.63 & 1.80 & 10.43 & 2.95 & 2.05 & 0.40 & 40.00 & 135 \\
\hline TAX & CORPTX & 29.91 & 30.00 & 5.79 & -0.27 & -0.19 & 17.00 & 40.69 & 150 \\
\hline
\end{tabular}

Note. Constructs: ECO is the 'Economy Construct'; CAP. MARK is the 'Depth of Capital Market Construct'; INVEST. PROTEC is the 'Investor Protection Construct'; ENTERP is the 'Entrepreneurship Construct'; HSE is the 'Social and Environmental Development Construct'; and TAX is the 'Taxation Construct'. Variables: GDPPC is Gross Domestic Product per Capita; GDPGROW is the yearly grow of Gross Domestic Product (\%); PRICELVL is the increase in the general price level of goods and services; IPO is IPO volume in \% of GDP; IPON is the number of IPOs; BANK is the number of banks per 100,000 inhabitants; MA is the amount negotiated in Merger and Acquisitions; MANEG is the number of Merger and Acquisitions; BOLSAN is the number of listed companies; CREDPRIV is the amount of private credit by deposit banks and others financial institutions ( $\%$ of GDP); DISCINDEX is the World Bank disclosure index that measures the extent to which investors are protected through disclosure of ownership and financial information. Ranges from 0 (less disclosure) to 10 (more disclosure); SHAREHD is the World Bank index that measures the shareholders' ability to sue officers and directors for misconduct. The index ranges from 0 (little to no ability to file suit) to 10 (greater ability to file suit); LEGAL is the strength of legal rights index that measures the level to which collateral and bankruptcy laws protect the rights of borrowers and lenders and thus facilitate lending. Ranges from 0 (weak) to 12 (strong); PROCEDE is the number of procedures to start a new business; CUSTO is the cost to start a new business (\% of GDP per capita); MARCA is the number of new patents; PESQUI is the number of full-time researchers (per 1,000,000 habitants); GASTOPRIM is the government expenditure on primary education ( $\%$ of GDP); GASTOSEC is the government expenditure on secondary education (\% of GDP); NETUSERS is the number of internet users (per 100 habitants); TELFIXO is the number of telephones (per 100 habitants); NETSUBS is the number of internet subscriptions (per 100 inhabitants); CPI is the Corruption Perception Index. Ranges from 0 (more perception of corruption) to 10 (less perception of corruption); HOM is the number of homicides (per 100,000 habitants); CORPTX is the Corporative Tax $(\%)$.

Fávero et al. (2009) state that an assessment of the technical suitability is essential by means of some tests, which are presented below. The first one is the Correlation Matrix Analysis, seeking to identify significant relation, greater than 0.3 , to justify the use of this method. The next step is the analysis of the KMO statistic, which needs to be greater than 0.5 in a range between 0 and 1; Bartlett's test, in turn, examines the null hypothesis of the correlation matrix to be an identity matrix with the determinant equal to one. Once rejected, it means that the variables are correlated. After that, an Antiimage matrix has to be analyzed investigating whether any specific variable have to be dropped, so that values below and above the main diagonal reveal the inadequacy of the method.

Table 4 presents the total of the explained variance, revealing the number of factors of each construct. Furthermore, it shows the KMO statistic and also, for the Bartlett's test, presents the ChiSquared with significance represented by the number of stars $(*)$. 
Table 4

Total of Explained Variance, KMO and Bartlett's Test

\begin{tabular}{|c|c|c|c|c|c|c|c|c|}
\hline \multirow[t]{2}{*}{ Comp. } & \multicolumn{3}{|c|}{ Eigenvalues } & \multicolumn{3}{|c|}{$\begin{array}{c}\text { Extractions Sums of Squared } \\
\text { Loadings }\end{array}$} & \multirow{2}{*}{ KMO } & \multirow{2}{*}{ Bartlett } \\
\hline & Total & $\begin{array}{c}\% \text { of } \\
\text { Variance }\end{array}$ & Cumulative \% & Total & $\begin{array}{c}\% \text { of } \\
\text { Variance }\end{array}$ & Cumulative \% & & \\
\hline \multicolumn{9}{|c|}{ Panel A - Economy } \\
\hline 1 & 1.697 & 56.578 & 56.578 & 1.697 & 56.578 & 56.578 & 0.542 & $64.118^{*}$ \\
\hline 2 & 0.843 & 28.087 & 84.665 & & & & & \\
\hline \multicolumn{9}{|c|}{ Panel B - Intensity of Capital Market activity } \\
\hline 1 & 4.193 & 59.902 & 59.902 & 4.193 & 59.902 & 59.902 & \multirow{3}{*}{0.775} & \multirow{3}{*}{ 773.873* } \\
\hline 2 & 1.266 & 18.086 & 77.987 & 1.266 & 18.086 & 77.987 & & \\
\hline 3 & 0.612 & 8.747 & 86.734 & & & & & \\
\hline \multicolumn{9}{|c|}{ Panel C - Investor Protection } \\
\hline 1 & 1.592 & 53.062 & 53.062 & 1.592 & 53.062 & 53.062 & 0,541 & $47.875^{*}$ \\
\hline 2 & 0.894 & 29.806 & 82.868 & & & & & \\
\hline \multicolumn{9}{|c|}{ Panel D - Friendly environment for entrepreneurship } \\
\hline 1 & 1.648 & 54.928 & 54.928 & 1.648 & 54.928 & 54.928 & 0,548 & $47.875^{*}$ \\
\hline 2 & 0.962 & 32.055 & 86.983 & & & & & \\
\hline \multicolumn{9}{|c|}{ Panel E- Social Development } \\
\hline 1 & 5.364 & 67.044 & 67.044 & 5.364 & 67.044 & 67.044 & $\mathbf{0 , 8 8 3}$ & $728.324 *$ \\
\hline 2 & 0.829 & 10.358 & 77.402 & & & & & \\
\hline
\end{tabular}

Note. We choose to highlight the extracted factors in each construct.

Significance Level: * Significant at $1 \%$

Panel E (Social and Environmental Development) presented the biggest explained variance, with a $67.04 \%$ total. The results of Table 3 show that all the constructs have formed a single factor, except for the Capital Market. This one was split in two factors to explain $77.98 \%$ of the variables variance. After evaluating the structure of these factors, it was possible to differentiate them through the variables that composed these factors: the first factor has grouped variables related to the capital market and the second factor has added variables of financial institutions and banks.

Table 5 below summarizes the number of factors formed in each construct, as well as their names. It is worthy to note that Capital Market was divided in MCAP and BANK. 
Table 5

Factors Summary

\begin{tabular}{ccc}
\hline Construct & Number of Factors & Factor Name \\
\hline Economy Activity & 1 & ECO \\
\hline Intensity of Capital Market activity & 2 & $\begin{array}{l}\text { MCAP } \\
\text { BANK }\end{array}$ \\
\hline Investor Protection & 1 & INVPROT \\
\hline $\begin{array}{c}\text { Friendly Environment for } \\
\text { Entrepreneurship }\end{array}$ & 1 & EMP \\
\hline Social Development & 1 & DSO \\
\hline
\end{tabular}

The results of the factor analysis changed the econometric models because they were increased by a new variable once the construct Capital Markets resulted in two factors: the first variable with the capital market characteristics (Label: MCAP) and the second factor variable with banking system characteristics (Label: BANK). Thus, the econometric models can be described by the following equations:

$$
\begin{aligned}
& F_{U N D R_{i}}=\beta_{0}+\beta_{1} E C O_{i}+\beta_{2} M_{C A P_{i}}+\beta_{3} B_{A N K_{i}}+\beta_{4} I N V P R O T_{i}+\beta_{5} D_{S O}+ \\
& \beta_{6} E M P_{i}+\beta_{7} C_{C O R P T X}+\varepsilon_{i} \\
& I N V M_{i}=\beta_{0}+\beta_{1} E_{C O}+\beta_{2} M_{C A P}+\beta_{3} B_{A N K_{i}}+\beta_{4} I N V P R O T_{i}+\beta_{5} D_{S O}+ \\
& \beta_{6} E_{M P P_{i}}+\beta_{7} \operatorname{CORPTX}_{i}+\varepsilon_{i}
\end{aligned}
$$

This division of the construct corresponds to the Black and Gilson (1998) proposition and, therefore, $\beta_{2}$ is expected to be positive, while $\beta_{3}$ is expected to signalize a negative relationship with the dependent variable. In the next subsections we estimate the correlation matrix and regression models to analyze the coefficients.

\section{Correlation Matrix}

We evaluated existence of almost exact linear dependencies among the independent variables, which would result in the instability to estimated coefficients and models as a whole. There is some complexity in an attempt to accurately assess the individual effects of explanatory variables on the dependent variable, since they can be naturally related.

Because of this possible natural relationship, it is important to evaluate among the regressors what level and type of relationship exists among them. Possible evidence of these relationships can be found in the correlation matrix (Table 6): 
Table 6

\section{Correlation Matrix}

\begin{tabular}{lccccccc}
\hline & ECO & MCAP & BANK & INVPROT & EMP & DSO & CORPTX \\
\hline ECO & 1 & & & & & & \\
MCAP & $0.3374^{*}$ & 1 & & & & & \\
BANK & $0.4616^{*}$ & 0.1117 & 1 & & & & \\
INVPROT & 0.1200 & $0.3634^{*}$ & $-0.1766^{* *}$ & 1 & & & \\
EMP & $\mathbf{0 . 6 1 3 7 *}$ & 0.0922 & $0.2508^{*}$ & $0.2630^{*}$ & 1 & & \\
DSO & $\mathbf{- 0 . 7 8 9 9 *}$ & $-0.3645^{*}$ & $-0.4774^{*}$ & $-0.1649 * *$ & $\mathbf{- 0 . 6 5 9 3 *}$ & 1 & \\
CORPTX & -0.0225 & $0.1383^{* * *}$ & 0.0064 & $0.2631^{*}$ & $-0.2121 *$ & 0.0995 & 1 \\
\hline
\end{tabular}

Note. Table 6 shows the correlation matrix of the variables used in the study for indication of multicollinearity problems. We choose to highlight the variable pairs that could cause multicollinearity. Variables: ECO is a variable of 'Economy Construct'; MCAP is a variable of Capital Market in 'Intensity of Capital Market activity Construct'; BANK is a variable of bank system in 'Intensity of Capital Market activity Construct'; INVPROT is a variable of 'Investor Protection Construct'; EMP is variable of 'Entrepreneurship Construct'; DSO is a variable of 'Social Development Construct'; and CORPTX is a variable to Taxation.

Significance Level: * Significant at 1\%;** Significant at 5\%;*** Significant at $10 \%$.

It is possible to infer that absolute correlations higher than 0.80 indicate strong linear association and relationship collinear detrimental to the model (Hill, Griffiths, \& Judge, 2010). By visual inspection, none of the variables in the correlation table exceeded the acceptable level, but three pairs of variables (ECO-EMP, ECO-DSO and DSO-EMP) obtained correlation values that were near to the critical point.

For this reason, we modeled auxiliary regressions (not reported) among the independent variables searching for multicollinearity problems. When variables ECO, DSO and EMP were used as dependent variables, these obtained $\mathrm{r}^{2}$ coefficient of $0.669,0.579$ and 0.716 , respectively. We conclude that none of the independent variables is highly collinear with any other because the $\mathrm{R}^{2}$ coefficients of the auxiliary regressions were not greater than 0.80 (Hill et al., 2010).

Before reporting the results of the regressions we tested some assumptions:

Homoscedasticity: The Breusch-Pagan test for E3 equation resulted in Chi-Square of 420.74 (p-value $<0.0001$ ), and 383.72 (p-value < 0.0001) for E4 equation, rejecting the null hypothesis of homoscedasticity of residues. As a corrective measure we used the White's robust correction.

Normality: The Asymmetry/Kurtosis test for Normality was used where the null hypothesis is normality of residues. This test resulted in statistical chi-square of 24.97 (p-value $<0.0001$ ) for the E3 model and chi-square statistic of 18.34 (p-value < 0.0001) for the E4 model, rejecting the null hypothesis of normality. Despite the results, we used the recommendations of Brooks (2008) and Levine, Berenson and Stephan (2005) which emphasize that for sample sizes that are sufficiently large, violation of the normality assumption is virtually inconsequential. Based on the central limit theorem, the authors have emphasized that the test statistics will asymptotically follow the appropriate distributions even in the absence of error normality.

\section{Econometric Results}

In this topic, we report the econometric results of demand and supply sides together: 
Table 7

Econometric Results: Both Sides

\begin{tabular}{ccccc}
\hline \multirow{2}{*}{ Variables } & \multicolumn{2}{c}{ (FUNDR) } & \multicolumn{2}{c}{ (INVM) } \\
\cline { 2 - 5 } ECO & Robust & Fixed Effects & Robust & Fixed Effects \\
& $\mathbf{4 1 0 0 . 9 4 * * *}$ & $\mathbf{7 8 9 0 . 7 2} * *$ & -2788.25 & $\mathbf{- 1 9 9 0 . 0 1 * *}$ \\
MCAP & $\mathbf{2 1 8 0 . 4 6 )}$ & $\mathbf{( 3 8 0 7 . 0 5 )}$ & $(1917.81)$ & $\mathbf{( 7 9 9 . 1 9 )}$ \\
& $\mathbf{4 9 4 3 1 . 2 8 *}$ & $\mathbf{7 5 2 3 0 . 7} *$ & $\mathbf{3 1 2 3 . 9 9 * *}$ & $\mathbf{2 7 0 5 . 2 5 * * *}$ \\
BANK & $\mathbf{( 5 9 9 7 . 0 6 )}$ & $\mathbf{( 6 5 4 4 . 5 4 )}$ & $\mathbf{( 1 3 0 0 . 6 9 )}$ & $\mathbf{( 1 3 7 3 . 8 6 )}$ \\
& $\mathbf{- 1 7 1 5 9 *}$ & $\mathbf{- 1 8 0 0 4 . 3 7 *}$ & $\mathbf{- 2 1 9 8 . 5 3 * * *}$ & $\mathbf{- 2 0 4 3 . 6 2 * * *}$ \\
GC & $\mathbf{( 2 9 2 1 . 1 8 )}$ & $\mathbf{( 5 1 6 6 . 6 3 )}$ & $\mathbf{( 1 1 7 2 . 7 6 )}$ & $\mathbf{( 1 0 8 4 . 6 0 )}$ \\
& $\mathbf{- 5 5 4 6 . 5 3 *}$ & $\mathbf{- 1 7 8 5 8 . 5 6 *}$ & $\mathbf{1 4 1 4 . 3 5 * * *}$ & 1335.97 \\
EMP & $\mathbf{( 1 7 6 8 . 2 5 )}$ & $\mathbf{( 3 3 8 1 . 8 5 )}$ & $\mathbf{( 7 3 5 3 . 3 5 )}$ & $(2900.85)$ \\
& $\mathbf{6 4 9 9 *}$ & 2735 & $\mathbf{2 3 7 7 . 5 3 * *}$ & -675.23 \\
DSO & $\mathbf{( 2 1 0 3 )}$ & $(10218.07)$ & $\mathbf{( 1 1 6 1 . 3 3 )}$ & $(2145.02)$ \\
& $\mathbf{8 8 9 0 . 1 6 *}$ & -11431.03 & $\mathbf{7 3 9 8 . 2 8 *}$ & 518.90 \\
CORPTX & $\mathbf{( 2 4 7 5 . 6 7 )}$ & $(8801.96)$ & $(\mathbf{2 6 8 5 . 6 5 )}$ & $(1847.75)$ \\
& $\mathbf{- 5 1 0 . 0 1 * * *}$ & 168.48 & -12.665 & -127.15 \\
CONSTANT & $\mathbf{( 2 8 2 . 4 3 )}$ & $(965.40)$ & $(108.42)$ & $(202.66)$ \\
& $\mathbf{3 0 9 7 3 . 3 9 *}$ & 10314 & 4816.99 & 8845.59 \\
Observations & $\mathbf{( 8 8 4 2 . 0 3 )}$ & $(29291.73)$ & $(3942.40)$ & $(6149.06)$ \\
R-squared & 150 & 150 & 150 & 150 \\
Adj R-squared & 0.848 & 0.644 & 0.165 & 0.175 \\
F Stat & 0.840 & 0.478 & 0.124 & 0.139 \\
\hline & $\mathbf{1 0 . 5 9 *}$ & $\mathbf{2 3 . 9 6 *}$ & $\mathbf{3 . 7 0} *$ & $\mathbf{4 . 1 8 *}$ \\
\hline
\end{tabular}

Note. Variables: ECO is a variable of 'Economy Construct'; MCAP is a variable of Capital Market in 'Depth of Capital Market Construct'; BANK is a variable of bank system in 'Depth of Capital Market Construct'; INVPROT is a variable of 'Investor Protection Construct'; EMP is variable of 'Entrepreneurship Construct'; DSO is a variable of 'Social and Environmental Development Construct'; and CORPTX is a variable to Taxation.

Significance Level: * Significant at 1\%;** Significant at 5\%;*** Significant at $10 \%$.

On the demand side (VAR: INVM), the explanatory variables presented statistically significant coefficients for the variables MCAP and EMP at 5\% of significance level. The variables BANK and INVPROT have presented significant coefficients at $10 \%$ of significance, and DSO at $1 \%$ of significance level. CORPTX and ECO were not significant. However, from the fixed effects regression it shows the variable ECO as negative and significant.

One possible explanation is the pursuit of differentiated returns by PE / VC fund managers in countries whose economic activity is still in a maturing process. In developed markets the scenario is reversed since they have difficulty in maintenance of profitability of the early 90s (Comodo, 2009). The result seems controversial but its lack of significance highlights the importance of the capital market (through IPOs as a way of disinvestment) as key drivers of PE/VC market. Similar results can be found in Jeng and Wells (2000, p. 32) who claim that "the absence of significance on our macroeconomic variable, GDP growth, underscores the importance of IPOs as the main explanatory factor for venture capital and private equity investments".

The coefficients of the factors MCAP and BANK corroborate international literature having a positive relationship with the first variable (Gompers \& Lerner, 1998; Jeng \& Wells, 2000) and a 
negative one with the second (Black \& Gilson, 1998). Through relationship, it is possible to infer that the capital market positively influences the generation and maintenance of a vibrant PE/VC market. Inversely, the banking system has a negative effect, which weakens the PE/VC market. One possible explanation is the necessity $\mathrm{PE} / \mathrm{VC}$ funds have for an exit strategy. Among the possibilities, the capital market provides an efficient and widely used way out for companies financed by PE/VC funds: the IPO.

The investor protection factor (INVPROT) resulted in positive and significant relationship (significance level: 10\%). The result confirms, on the demand side, those found out by La Porta et al. (1997) who state that a structured legal environment protects potential financiers of being expropriated, which increases the willingness to allocate their financial resources on riskier investments such as stock, which in turn enhances the participation of PE/VC funds.

The variable of entrepreneurial culture (EMP) resulted in a positive and significant coefficient, confirming the findings of previous studies (Gompers \& Lerner, 1998; Romain \& Pottelsberghe de la Potterie, 2004). The result of this variable relates to the findings by Gompers and Lerner (1998, p. 188) which concluded that "the greater the number of good firms, the greater the demand for Venture Capital”.

The corporate tax value was not significant. One possible explanation is that the levels of taxation in the sample are too close and did not change over time and therefore do not impact the PE/VC market. This means that for a government to influence the local PE/VC market, it should offer discount rates or high tax incentives, enough to mitigate the effect of other barriers faced by PE/VC market.

The Social Development factor (DSO) has a significant impact on the demand side: the sub-levels of the construct help to explain the investments of PE/ VC funds. Given the construct characteristics, the most difficult task was to find variables that could properly identify it. Besides variables like education and crime, communication is also important, since it impacts startups linked to the technology sector (app companies for example). This could be crucial in an investment decision due to the dependence of this market on technological infrastructure for dissemination and functioning of products.

On the supply side the variable for economic activity was significant only at $10 \%$, contrary to the difference found by Jeng and Wells (2000) but in accordance with the evidence of Gompers and Lerner (1998). Again the MCAP and BANK variables were significant and their coefficients had their signs as expected and proposed in the literature.

The INVPROT variable resulted in a negative and significant coefficient which is contrary to the results found by La Porta et al. (1997). This result obtained a different signal from that obtained on the demand side, a condition that evidences that the motivations of agents change according to the financial flow: while on the supply side, fundraising is adversely affected when there is greater protection to investors, funds seek better protective conditions to put money on the demand.

The level of entrepreneurship resulted in a sign as expected: the positive impact shows that the supply side is also sensitive to the number of new businesses. As well as on the demand side, the Social Development factor was significant and positive. This means that for solid investments by funds to become effective, the environment must provide qualified persons, low criminality, and quality communication structure.

Taxation has a negative and weak significant impact (significant at $10 \%$ level only) on the supply side and shows that, in comparison with other factors, this is the one of least impact. It reinforces the idea that for greater impact, higher discount rates or incentives should be provided for both the demand and the supply sides.

In order to check the robustness of the results additional regressions were made applying natural logarithm in the dependent variable for each model. This change in the dependent variable aims to reduce the difference in magnitude between it and the independent variables. The results presented in the Appendix show that there are few changes from the main results reported, and these alterations have 
low impact on the analysis and conclusions. Since there was no sign of change, only small changes in levels of significance, these do not impact the analyses substantially.

\section{Discussions}

Despite the increasing growth in recent years, the PE/VC market faces challenges to its stabilization, since it is influenced by regional characteristics. One is the cultural differences in willingness to make riskier investments as pointed out by Black and Gilson (1998). A possible solution for investors in conservative cultures would be investing in geographically distant companies, but the cost of monitoring can explain why this solution does not occur in practice (despite the Israeli case, see Jeng \& Wells, 2000).

The results show that there is dependence between the capital market and the PE/VC market, but also suggest that the shrinkage of the PE/VC market may occur due to the lack of secondary institutions that support fundraising and investment activities. Thus, to attract investors, a local infrastructure with ability to find lucrative opportunities, smooths the bureaucratic issues and ensure compliance with the contracts is required.

Another possible cause is that investment in PE/VC activities often goes beyond the allocation of financial resources, given that a non-financial contribution (management activities) is common. However, the latter is an uncommon fact among investors in the banking system.

Overall, it was understood that stimulating the analyzed constructs singly, may be an ineffective way to strengthen the PE/VC market. For example, countries which reduce taxes in PE/VC transactions as incentive to this market cannot attract the attention of the PE/VC managers if they have high rates of unemployment, corruption and bribery.

\section{Concluding Remarks}

Our methodological structure consisted of a descriptive analysis, a factor analysis and multiple regressions. The results were achieved by econometric models with a sample of six years (2006-2011) and twenty-five countries and we employed factor analysis in order to condense the twenty-five variables that characterize the six constructions. Among the results, our greatest contribution consists of the evidence concerning the importance of the capital market to a higher level of fundraising: dynamic stock markets, with many public offerings guarantee liquidity to the PE/VC market, which allows funds a way of safe divestment.

Our results reinforce the findings in the literature: a positive relationship between the levels of financing generated by PE/VC funds and the depth of the capital market. The demand and supply side of PE/VC market proved strongly sensitive to the volume traded in the stock market, the number of IPOs and the number of M\&A, for example. This explains, for example, the reason for the US being the biggest PE/VC market. Obviously this is not the only factor, but it is the most relevant. In general, there is a dependency between the depth of the capital market and the amount of funds raised.

The evidences confirm the impacts of economic activity on the supply side as proposed by Romain and Pottelsbergue de la Potterie (2004). But some prudence is necessary regarding that result: lack of strength on the significance should be further analyzed using larger samples or longer periods. The protection of investors proved controversial: while it proved to be negative on the supply side, its signal was inverted on the demand side. Possibly, PE/VC funds seek greater protections in their investments than they that are willing to deliver to its investors. 
The PE/VC market is positively affected by the Social and Environmental Development factor at both ends. This shows that a PE/VC market growth occurs when the environment provides resources and ideal conditions. Reversing the idea, it could be argued that the PE/VC market tends to start with a greater chance of success in locations where there is low crime, qualified people available, and a quality communication structure.

The results reveal the importance of these constructs to PE/VC market, but it is clear, for example, that the depth of the capital market has greater impact than taxation. Conclusions as the one discussed in this study can impact recent research as that of Groh et al. (2010) which, for the construction of attractiveness indices, considered these constructs equally.

Our research has a variety of practical implications for those interested in stimulating the PE/VC market: in fundraising, the evidences indicates that specific policies are necessary to the greater commitment in the PE/VC market, or rather; current policies have not had the desired effect, at least in the sampled countries.

\section{Acknowledgements}

The authors gratefully acknowledge the contributions of Paul Victor Gomes Novaes, Luiz Cláudio Louzada (UFES) and Alfredo Sarlo Neto (UFES).

\section{References}

Agência Brasileira de Desenvolvimento Industrial. (2011). A indústria de private equity e venture capital $-2^{\circ}$ censo brasileiro. Retrieved from http://www.abdi.com.br/Estudo/Private_Equity_e_Venture_Censo.pdf

Almeida, A. A. (2013). A influência do private equity e venture capital sobre a informatividade dos lucros no mercado brasileiro (Dissertação de mestrado). Programa de Pós-Graduação em Ciências Contábeis, Universidade Federal do Espírito Santo, Espírito Santo, Brasil. Retrieved from http://portais4.ufes.br/posgrad/teses/tese_5939_DISSERTA\% C7\%C3O\%20ANDR\% C9\% 20PDF.pdf

Armour, J., \& Cumming, D. (2008). Bankruptcy law and entrepreneurship. American Law and Economics Association, 10(2), 303-350. doi: 10.1093/aler/ahn008

Balboa, M., \& Martí, J. (2004, June/July). An integrative approach to the determinants of private equity fundraising. Proceedings of the EFMA 2004 Basel Meetings Paper, Basel, Switzerland.

Bain \& Company, Inc. (2013). Global private equity report. Retrieved from http://www.bain.com/Images/BAIN_REPORT_Global_Private_Equity_Report_2013.pdf

Baughn, C. C., \& Neupert, K. E. (2003). Culture and national conditions facilitating entrepreneurial start-ups. Journal of International Entrepreneurship, 1(3), 313-330. doi: 10.1023/A:1024166923988

Black, B. S., \& Gilson, R. J. (1998). Venture capital and the structure of capital markets: banks versus stock markets. Journal of Financial Economics, 47(3), 243-277. doi: 10.1016/S0304$405 \mathrm{X}(97) 00045-7$

Brooks, C. (2008). Introductory econometrics for finance (2nd ed.). Cambridge: Cambridge University Press. 
Comodo, G. C. (2009). Uma análise comparativa entre as estruturas de private equity e venture capital nos EUA e no Brasil (Dissertação de mestrado). Escola de Administração de Empresas de São Paulo, Fundação Getúlio Vargas, São Paulo, SP, Brasil.

Cullen, J., \& Gordon, H. R. (2002). Taxes and entrepreneurial activity: theory and evidence for the U.S. [Working Paper $n^{\circ}$ 9015]. National Bureau of Economic Research, Cambridge, MA.

Cumming, D., Fleming, G., \& Schwienbacher, A. (2006). Legality and venture capital exits. Journal of Corporate Finance, 12(2), 214-245. doi: 10.1016/j.jcorpfin.2004.12.004

Engel, D. (2002). The impact of venture capital on firm growth: an empirical investigation [ZEW Discussion Paper $\mathrm{n}^{\circ}$ 02-02]. ZEW - Centre for European Economic Research, Mannheim, Germany. Retrieved from http://ssrn.com/abstract=319322

Fávero, L. P., Belfiore, P., Silva, F. L., \& Chan, B. L. (2009). Análise de dados: modelagem multivariada para tomada de decisões. Rio de Janeiro: Elsevier.

Frieden, R. (2005). Lessons from broadband development in Canada, Japan, Korea and the United States. Telecommunications Policy, 29(8), 595-613. doi: 10.1016/j.telpol.2005.06.002

Gionelli, S. P. O. (2008). Os gestores de private equity e venture capital influenciam a governança corporativa das investidas? Evidências das empresas estreantes na Bovespa (Dissertação de mestrado). Escola de Administração de Empresas de São Paulo, Fundação Getúlio Vargas, São Paulo, SP, Brasil.

Gompers, P. A., \& Lerner, J. (1998). What drives venture fundraising? Brooking Papers on Economic Activity: Microeconomics, 149-204. Retrieved from http://www.brookings.edu/ /media/projects/bpea/1998-micro/1998_bpeamicro_gompers.pdf

Gompers, P., \& Lerner, J. (2001). The venture capital revolution. Journal of Economic Perspectives, 15(2), 145-168. doi: 10.1257/jep.15.2.145

Groh, A. P., Liechtenstein, H. von, \& Lieser, K. (2010). The European venture capital and private equity country attractiveness indices. Journal of Corporate Finance, 16(2), 205-224. doi: 10.1016/j.jcorpfin.2009.09.003

Hair, J., Black, W. C, Babin, B. J., Anderson, R. E., \& Tatham, R. L. (2005). Multivariate data analysis. Upper Saddle River, NJ: Pearson Prentice Hall.

Hellmann, T., \& Puri, M. (2002). Venture capital and professionalization of start-up firms: empirical evidence. Journal of Finance, 57(1), 169-197. doi: 10.1111/1540-6261.00419

Hill, R. C., Griffiths, W. E., \& Judge, G. G. (2010). Econometria. São Paulo: Saraiva.

Jeng, L., \& Wells, P. C. (2000). The determinants of venture capital funding: evidence across countries. Journal of Corporate Finance, 6(3), 241-289. doi: 10.1016/S0929-1199(00)00003-1

Jensen, M. C. (1989). Eclipse of the public corporation. Harvard Business Review, 67, 61-74. Retrieved from https://hbr.org/1989/09/eclipse-of-the-public-corporation

Kaplan, S. (1989). The effects of management buyouts on operating performance and value. Journal of Financial Economics, 24(2), 217-254. doi: 10.1016/0304-405X(89)90047-0

Kaplan, S., \& Schoar, A. (2005). Private equity performance: returns, persistence, and capital flows. The Journal of Finance, 60(4), 1791-1823. doi: 10.1111/j.1540-6261.2005.00780.x

Kim, J. O., \& Muller, C. W. (1978). Introduction to factor analysis: what it is and how to do it. Beverly Hills, California: Sage. 
Kortum, S., \& Lerner, J. (2000). Assessing the contribution of venture capital to innovation. The RAND Journal of Economics, 31(4), 674-692. doi: 10.2307/2696354

La Porta, R., Lopez-de-Silanes, F., Shleifer, A., \& Vishny, R. W. (1997). Legal determinants of external finance. The Journal of Finance, 52(3), 1131-1150. doi: 10.1111/j.1540-6261.1997.tb02727.x

Lee, S. M., \& Peterson, S. J. (2000). Culture, entrepreneurial orientation, and global competitiveness. Journal of World Business, 35(4), 401-416. doi: 10.1016/S1090-9516(00)00045-6

Levine, D. M., Berenson, M. L., \& Stephan, D. (2005). Estatística: teoria e aplicações - usando microsoft excel. Rio de Janeiro: LTC Ed.

Lopes, A. B., \& Furtado, C. V. (2006). Private equity na carteira de investimentos das entidades de previdência privada. Revista Contabilidade \& Finanças, 7(2), 108-126. doi: 10.1590/S151970772006000500009

Megginsson, W. L. (2002). Towards a global model of venture capital? Journal of Applied Corporate Finance, 16(1), 89-107. doi: 10.1111/j.1745-6622.2004.tb00599.x

Muscarella, C. J., \& Vetsuypens, M. R. (1990). Efficiency and organizational structure: a study of reverse LBOs. The Journal of Finance, 45(5), 1389-1413. doi: 10.1111/j.15406261.1990.tb03720.x

Phalippou, L., \& Gottschalg, O. (2009). The performance of private equity funds. The Review of Financial Studies, 22(4), 1747-1776. doi: 10.1093/rfs/hhn014

Romain, A., \& Pottelsberghe de la Potterie, B. van (2004). The determinants of venture capital: a panel data analysis of 16 OECD countries [Working Paper WP-CEB 04/015]. Research Institute in Management Sciences, Université Libre de Bruxelles, Brussels.

Schertler, A. (2003). Driving forces of venture capital investments in Europe: a dynamic panel data analysis [Working Paper, n 1172]. Kiel Institute for the World Economy, Kiel, Germany.

\section{Authors' Profiles}

Ricardo dos Santos Dias

Av. Fernando Ferrari, 514, Goiabeiras, 29075-910, Vitória, ES, Brazil. E-mail address: ricardodossantosdias@ gmail.com

Marcelo Alvaro da Silva Macedo

Av. Pasteur, 250, sala 249, 22290-902, Rio de Janeiro, RJ, Brazil. E-mail address: malvaro@facc.ufrj.br 


\section{APPENDIX}

Additional Econometric Results: Both Sides with Log on Dependent Variable

\begin{tabular}{|c|c|c|c|c|}
\hline \multirow{2}{*}{ Variables } & \multicolumn{2}{|c|}{ (LnFUNDR) } & \multicolumn{2}{|c|}{ (LnINVM) } \\
\hline & Robust & Fixed Effects & Robust & Fixed Effects \\
\hline \multirow[t]{2}{*}{ ECO } & 0.235 & $0.624 * *$ & $-0.497 *$ & $-0.629 * *$ \\
\hline & $(0.179)$ & $(0.264)$ & $(0.167)$ & $(0.285)$ \\
\hline \multirow{2}{*}{ MCAP } & $1.270^{*}$ & $1.370 *$ & $0.238 * * *$ & $0.531 * * *$ \\
\hline & $(0.121)$ & $(0.453)$ & $(0.139)$ & $(0.286)$ \\
\hline \multirow{2}{*}{ BANK } & $-\mathbf{0 . 1 7 7} * * *$ & $-0.633 * * *$ & $-0.504 *$ & $-0.192 * * *$ \\
\hline & $(0.104)$ & $(\mathbf{0 . 3 5 8})$ & (0.135) & $(0.114)$ \\
\hline \multirow{2}{*}{ GC } & $-0.185^{* * *}$ & $-0.585 * * *$ & $0.444^{* *}$ & 0.290 \\
\hline & $(0.109)$ & $(0.352)$ & $(0.174)$ & $(0.605)$ \\
\hline \multirow{2}{*}{ EMP } & $0.439 *$ & 0.327 & 0.167 & 0.438 \\
\hline & $(0.169)$ & $(0.708)$ & $(0.224)$ & $(0.447)$ \\
\hline \multirow{2}{*}{ DSO } & 0.704* & 0.226 & $1.956 *$ & -0.577 \\
\hline & (0.169) & $(0.610)$ & $(0.306)$ & $(0.385)$ \\
\hline \multirow{2}{*}{ CORPTX } & $-0.0815^{*}$ & $-0.145 * *$ & -0.0331 & -0.0100 \\
\hline & $(0.0208)$ & (0.0669) & $(0.0291)$ & $(0.0423)$ \\
\hline \multirow{2}{*}{ CONSTANT } & 4.834* & 2.933 & $5.010^{*}$ & $5.726^{*}$ \\
\hline & $(0.647)$ & (2.029) & $(0.854)$ & (1.282) \\
\hline Observations & 150 & 150 & 150 & 150 \\
\hline R-squared & 0.612 & 0.166 & 0.558 & 0.123 \\
\hline F-stat & 33.71* & $3.35^{*}$ & $25.12 *$ & $2.37 * *$ \\
\hline
\end{tabular}

Note. Robust standard errors in parentheses.

$* \mathrm{p}<0.01, * * \mathrm{p}<0.05, * * * \mathrm{p}<0.1$. 